Buletin Ilmiah Mat. Stat. dan Terapannya (Bimaster)

Volume 09, No. 1 (2020), hal 181-188.

\title{
PEMODELAN MATEMATIKA PENERJUN PAYUNG PADA POSISI TRACK SEBELUM PARASUT DIBUKA
}

\author{
Desi, Evi Noviani, Yudhi
}

\begin{abstract}
INTISARI
Pemodelan matematika dari pergerakan penerjun payung selama di udara sebelum parasut dibuka menggunakan pendekatan hukum Newton II, kemudian mencari model matematika penerjun payung sebelum parasut dibuka. Posisi penerjun mulai keluar dari pesawat sampai posisi siap membuka parasut adalah posisi track yaitu posisi dimana kepala penerjun menghadap serong ke bawah dan tangan sejajar dengan tubuh penerjun membentuk sudut 30 derajat. Selama di udara penerjun mengalami hambatan udara $(k)$ dan gaya gravitasi $(g)$. Kecepatan penerjun semakin ke bawah semakin meningkat sampai pada akhirnya penerjun mencapai kecepatan terminal yaitu kecepatan dimana gaya hambat udara besarnya sama dengan gaya gravitasi (gaya berat) penerjun. Posisi penerjun selama di udara dari permukaan tanah dapat dihitung $z(t)=z(0)-\frac{m g t \cos \alpha}{k}+\frac{m^{2} g \cos \alpha}{k^{2}}\left(-e^{-\frac{k}{m} t}+1\right)$, dengan $z(0)$ merupakan posisi awal penerjun dari permukaan tanah. Penerjun payung memiliki massa $85 \mathrm{~kg}$ (termasuk perlengkapan penerjun), penerjun melompat dari pesawat dengan ketinggian 5000 meter dan mencapai ketinggian 691,43 meter pada detik ke 35 sedangkan pada saat penerjun melompat dengan ketinggian 10000 meter, penerjun mencapai ketinggian 1553,20 meter pada detik ke 51. Pada ketinggian 691,43 meter merupakan waktu yang aman untuk penerjun membuka parasutnya selama di udara.
\end{abstract}

Kata kunci: Hukum Newton, gaya hambat udara, kecepatan terminal

\section{PENDAHULUAN}

Model matematika merupakan bentuk representasi atau penjabaran suatu permasalahan dalam dunia nyata yang dinyatakan dalam istilah matematika [1]. Banyak permasalahan yang ada di dunia nyata yang dapat dimodelkan dalam bentuk matematika. Salah satu permasalahan dalam dunia nyata yang dapat dimodelkan dalam bentuk matematika adalah olahraga terjun payung.

Terjun payung merupakan aktivitas terjun dari pesawat dengan menggunakan parasut. Terjun payung biasa dilakukan oleh pasukan khusus dunia kemiliteran untuk menyelesaikan misinya di suatu wilayah terpencil. Olahraga terjun payung telah berkembang di seluruh dunia. Saat ini olahraga terjun payung tidak hanya melibatkan kalangan militer saja melainkan masyarakat sipil sudah banyak yang merasakan olahraga ekstrim ini. Di Indonesia terjun payung tidak kalah populer dengan olahraga lainnya. Perlombaan terjun payung banyak diadakan setiap tahunnya ditingkat nasional maupun internasional. Beberapa lomba itu seperti accuracy (ketepatan mendarat), canopy formation (formasi parasut), dan skydive formation (formasi penerjun).

Pada saat melakukan penerjunan, penerjun selalu memperhatikan tiga hal, yaitu tekanan udara, ketinggian minimum awal dan jarak minimum dari titik yang akan dituju. Karena tiga hal tersebut sangat berpengaruh pada keselamatan penerjun dan kecepatan parasut. Berdasarkan hal tersebut, banyak ilmuan mengembangkan model matematika untuk permasalahan terjun payung. Model matematika untuk gerak jatuh bebas dibentuk berdasarkan hukum Newton II, yaitu $\sum F=m a$, dengan $m$ adalah massa penerjun termasuk perlengkapan yang digunakannya $(\mathrm{kg}), a$ adalah percepatan penerjun $\left(\mathrm{m} / \mathrm{s}^{2}\right)$ dan $\sum F$ adalah jumlah dari gaya gravitasi $\left(F_{g}\right)$ dan gaya hambat udara $\left(F_{d}\right)$ [2]. Di dalam dunia penerjunan banyak posisi yang dapat dilakukan penerjun selama di udara. Posisi tersebut adalah posisi Arch, Track, Sit, dan Stand. Pada penelitian ini membahas tentang posisi track penerjun selama di udara. 
Posisi track merupakan posisi dimana kepala penerjun menghadap serong ke bawah dan kedua tangan penerjun sejajar dengan tubuh. Posisi track ini menarik untuk diteliti karena masih banyak penerjun yang menggunakan posisi ini di udara.

Berdasarkan permasalahan tersebut maka penelitian ini berisi tentang bagaimana pergerakan dan posisi track penerjun ketika di udara, mulai melompat dari pesawat sampai pada posisi penerjun siap membuka parasut. Permasalahan tersebut dibawa ke dalam model matematika untuk diketahui berbagai pengaruh sebelum melakukan penerjunan. Oleh sebab itu penerjun bisa melakukan lompatan dengan selamat dan bisa mendarat pada posisi yang sudah ditentukan.

\section{PENERJUN PAYUNG}

Penerjun payung merupakan orang yang melakukan penerjunan dari ketinggian tertentu dengan menggunakan parasut. Penerjun harus memiliki mental dan keadaan fisik yang baik sebelum melakukan penerjunan. Pada umumnya penerjunan dilakukan menggunakan pesawat terbang. Ketinggian normal untuk melakukan penerjunan biasanya pada ketinggian 5000 meter [2]. Banyak posisi yang dapat dilakukan oleh penerjun saat di udara. Salah satu posisi penerjun selama di udara adalah posisi track, posisi dimana kepala penerjun menghadap serong ke bawah dan kedua tangan penerjun sejajar dengan tubuh. Posisi track ini banyak digunakan oleh penerjun payung selama melakukan penerjunan.

\section{PERSAMAAN DIFERENSIAL}

Persamaan Diferensial (PD) merupakan suatu bentuk persamaan yang memuat turunan satu atau lebih variabel tak bebas terhadap satu atau lebih variabel bebas [3]. Berdasarkan turunan fungsi terhadap variabel bebas, persamaan diferensial dibagi menjadi dua yaitu persamaan diferensial biasa dan persamaan diferensial parsial. Persamaan Diferensial Biasa (PDB) adalah persamaan yang memuat turunan fungsi yang memuat satu variabel bebas. Sedangkan Persamaan Diferensial Parsial (PDP) adalah persamaan yang memuat turunan-turunan parsial atau dapat dikatakan persamaan yang turunan fungsinya memuat lebih dari satu variabel bebas. Jika diambil $y(x)$ sebagai suatu fungsi satu variabel, dengan $x$ dinamakan variabel bebas dan $y$ dinamakan variabel tak bebas, maka suatu persamaan diferensial dinyatakan dalam bentuk [4]:

$$
F\left(x, y, \frac{d y}{d x}, \frac{d^{2} y}{d x^{2}}, \frac{d^{3} y}{d x^{3}}, \ldots, \frac{d^{n} y}{d x^{n}}\right)=0
$$

\section{DASAR PERSAMAAN GERAK}

Semua benda yang bergerak melewati fluida seperti air atau udara pasti menimbulkan gaya hambat udara yang cenderung memperlambat pergerakan baik di air atau udara. Pada penelitian-penelitian sebelumnya, pergerakan selalu diasumsikan hanya bergerak pada satu dimensi saja seperti contoh bola yang jatuh dari atas ke bawah dan seorang penerjun payung yang hanya bergerak ke arah vertikal saja namun tidak ada pergerakan ke arah horizontalnya dan tidak ada pengaruh angin. Dalam pemodelan, sebagian besar jurnal mengasumsikan bahwa gaya hambat udara yang memperlambat pergerakan dari bola atau penerjun payung berbanding lurus dengan kecepatan jatuhnya tubuh penerjun. Secara matematis persamaan diferensial linear untuk pergerakan didefiniskan sebagai berikut:

$$
m g-k v=m \frac{d v}{d t}
$$

dimana $k$ adalah hambatan udara $(\mathrm{kg} / \mathrm{s}), \mathrm{m}$ adalah massa dari tubuh penerjun dan perlengkapannya $(\mathrm{kg}), g$ adalah percepatan gravitasi bumi $\left(\mathrm{m} / \mathrm{s}^{2}\right)$ dan $v$ merupakan kecepatan penerjun $(\mathrm{m} / \mathrm{s})$.

\section{KINEMATIKA PENERJUN PAYUNG}

Pemodelan matematika pada penerjun payung dimulai dari penerjun keluar dari pintu pesawat, kemudian penerjun melakukan gerak jatuh bebas hingga posisi siap membuka parasut. 
Salah satu posisi penerjun di udara adalah posisi track. Posisi track ini banyak digunakan oleh penerjun selama di udara. Adapun gaya-gaya yang bekerja selama di udara saat benda jatuh bebas dapat dilihat pada Gambar 1

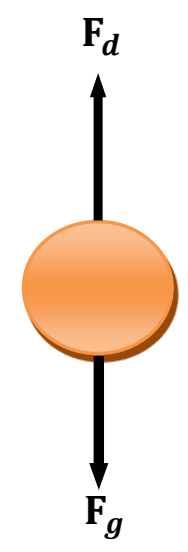

Gambar 1 Gaya-gaya yang bekerja pada benda jatuh bebas di udara

Pada saat penerjun mulai melompat dari pesawat maka hukum Newton II dapat diterapkan dan dalam hal ini penerjun diasumsikan melakukan gerak jatuh bebas. Secara matematis hukum Newton II dapat ditulis :

$$
\begin{gathered}
\sum F=m a \\
\text { dengan } \quad \sum F=F_{g}+F_{d}
\end{gathered}
$$

$F_{g}$ : gaya gravitasi penerjun payung $\left(\mathrm{kg} \mathrm{m} / \mathrm{s}^{2}\right)$

$F_{d}$ : gaya hambat udara $\left(\mathrm{kg} \mathrm{m} / \mathrm{s}^{2}\right)$

$m:$ massa penerjun dan perlengkapannya $(\mathrm{kg})$

$a$ : percepatan penerjun payung $\left(\mathrm{m} / \mathrm{s}^{2}\right)$

Percepatan merupakan hasil turunan pertama kecepatan terhadap waktu. Maka dapat ditulis:

$$
F_{g}+F_{d}=m \frac{d v}{d t}
$$

Sehingga didapat persamaan kecepatan penerjun terhadap waktu dengan nilai $c$ yang belum diketahui:

$v:$ kecepatan penerjun $\left(\mathrm{m} / \mathrm{s}^{2}\right)$

$$
v(t)=\frac{m g}{k}+c e^{-\frac{k}{m} t}
$$

$g$ : gravitasi bumi $\left(\mathrm{m} / \mathrm{s}^{2}\right)$

$k$ : hambatan udara $(\mathrm{kg} / \mathrm{s})$

Karena penerjun melakukan gerak jatuh bebas maka $v(0)=0$, sehingga didapat persamaan penerjun terhadap waktu:

$$
v(t)=\frac{m g}{k}\left(1-e^{-\frac{k t}{m}}\right)
$$

Untuk menentukan posisi penerjun terhadap waktu $(x(t))$ selama di udara dapat diperoleh dengan mengintegralkan persamaan kecepatan penerjun terhadap waktu, sehingga diperoleh:

$$
x(t)=\frac{m g t}{k}+\frac{m^{2} g e^{-\frac{k t}{m}}}{k^{2}}-\frac{m^{2} g}{k^{2}}
$$

Selanjutnya akan dicari posisi penerjun dari permukaan tanah. Misalkan $z(t)$ adalah posisi penerjun dari permukaan tanah pada saat $t$ dan posisi awal penerjun dari permukaan tanah adalah $z(0)$. 


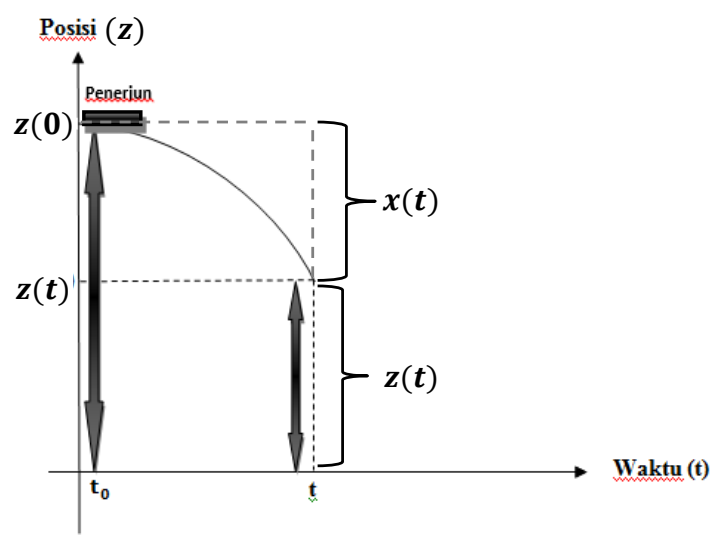

Gambar 2 Posisi penerjun pada saat $t$ dari permukaan tanah

Berdasarkan Gambar 2 maka diperoleh:

$$
z(t)=z(0)-x(t)
$$

Maka diperoleh persamaan posisi penerjun terhadap waktu dari permukaan tanah:

$$
z(t)=z(0)-\frac{m g t}{k}+\frac{m^{2} g}{k^{2}}\left(-e^{-\frac{k}{m} t}+1\right)
$$

\section{KINEMATIKA PENERJUN PAYUNG PADA POSISI TRACK}

Selama di udara banyak posisi yang dapat dilakukan oleh penerjun payung. Salah satunya adalah posisi track yaitu posisi dimana kepala penerjun menghadap serong ke bawah dan kedua tangan penerjun sejajar dengan tubuh. Diasumsikan penerjun payung keluar dari pesawat langsung membentuk posisi track. Maka konstruksi model matematika pada posisi track penerjun payung selama di udara dapat dilakukan dengan pendekatan hukum Newton II.

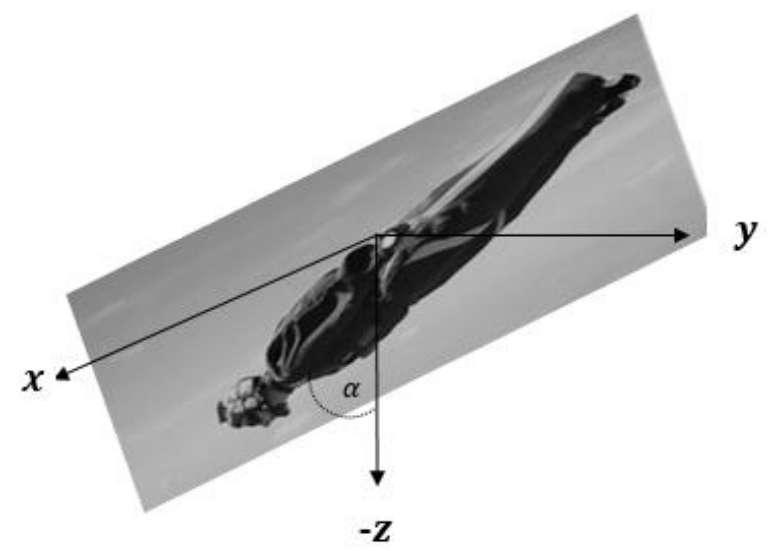

Gambar 3 Koordinat sumbu $x, y, z$ penerjun payung saat di udara [5]

Pada Gambar 3 penerjun payung diasumsikan hanya melakukan posisi track terhadap sumbu $Z$ dengan sudut $\alpha$. Penurunan rumus dimulai dengan hukum Newton II, sehingga dapat ditulis:

$$
\begin{gathered}
\sum F=m a \\
\text { dengan } \quad \sum F=F_{g}+F_{d}
\end{gathered}
$$


Percepatan merupakan hasil turunan pertama kecepatan terhadap waktu. Maka dapat ditulis:

$$
m g \cos a-k v=m \frac{d v}{d t}
$$

Sehingga didapat persamaan kecepatan penerjun terhadap waktu:

$$
v(t)=\frac{m g \cos \alpha}{k}+c e^{-\frac{k t}{m}}
$$

Karena penerjun melakukan gerak jatuh bebas maka $v(0)=0$, sehingga persamaan dapat ditulis:

$$
v(t)=\frac{m g \cos \alpha}{k}\left(1-e^{-\frac{k t}{m}}\right)
$$

Untuk menentukan posisi penerjun terhadap waktu $(x(t))$ selama di udara dapat diperoleh dengan mengintegralkan persamaan kecepatan penerjun terhadap waktu, sehingga diperoleh:

$$
x(t)=\frac{m g t \cos \alpha}{k}+\frac{m^{2} g \cos \alpha}{k^{2}} e^{-\frac{k t}{m}}-\frac{m^{2} g \cos \alpha}{k^{2}}
$$

Selanjutnya dicari posisi penerjun dari permukaan tanah. Misalkan $z(t)$ adalah posisi penerjun dari permukaan tanah pada saat $t$ dan posisi awal penerjun dari permukaan tanah adalah $z(0)$.

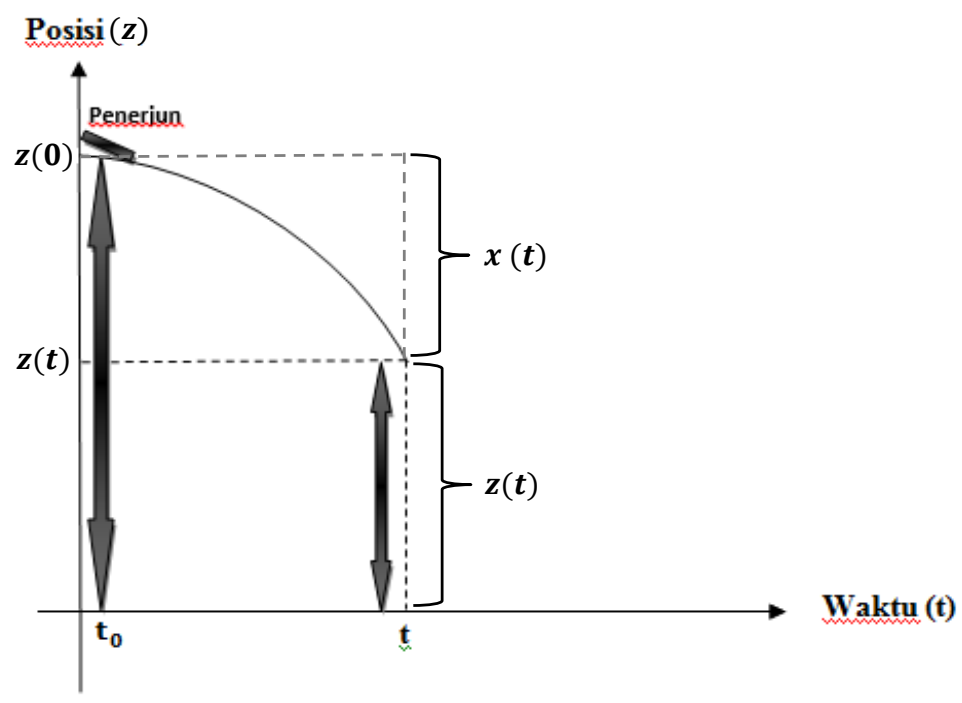

Gambar 4 Posisi penerjun pada saat $t$ dari permukaan tanah

Berdasarkan Gambar 4 maka diperoleh:

$$
z(t)=z(0)-x(t)
$$

Maka diperoleh persamaan posisi penerjun terhadap waktu dari permukaan tanah:

$$
z(t)=z(0)-\frac{m g t \cos \alpha}{k}+\frac{m^{2} g \cos \alpha}{k^{2}}\left(-e^{-\frac{k}{m} t}+1\right)
$$

\section{SIMULASI DAN ANALISIS}

Pada sub bab ini dilakukan simulasi dari persamaan-persamaan gerak terjun payung yang sudah diperoleh dari perhitungan sebelumnya. Dari hasil simulasi akan dilakukan analisa terhadap pergerakan penerjun payung sebelum parasut dibuka selama di udara. 
Tabel 1 Nilai parameter pada terjun payung

\begin{tabular}{ccc}
\hline Parameter & Nilai & Sumber \\
\hline$\alpha$ & $30^{\circ}$ & Asumsi \\
$g$ & 9.8 & {$[2]$} \\
$m$ & 85 & Asumsi \\
$k$ & 1,44 & {$[2]$} \\
$x_{0}$ & 5000 dan 10000 & Asumsi \\
$t$ & 35 dan 51 & Asumsi \\
\hline
\end{tabular}

Tabel 2 Simulasi pergerakan penerjun payung di udara sebelum parasut dibuka

\begin{tabular}{crc}
\hline Simulasi & $\boldsymbol{x}_{\mathbf{0}}$ & $\boldsymbol{t}$ \\
\hline $\mathrm{Ke}-1$ & 5000 meter & 35 detik \\
Ke-2 & 5000 meter & 35 detik \\
Ke-3 & 10000 meter & 51 detik \\
Ke-4 & 10000 meter & 51 detik \\
\hline
\end{tabular}

\section{SIMULASI}

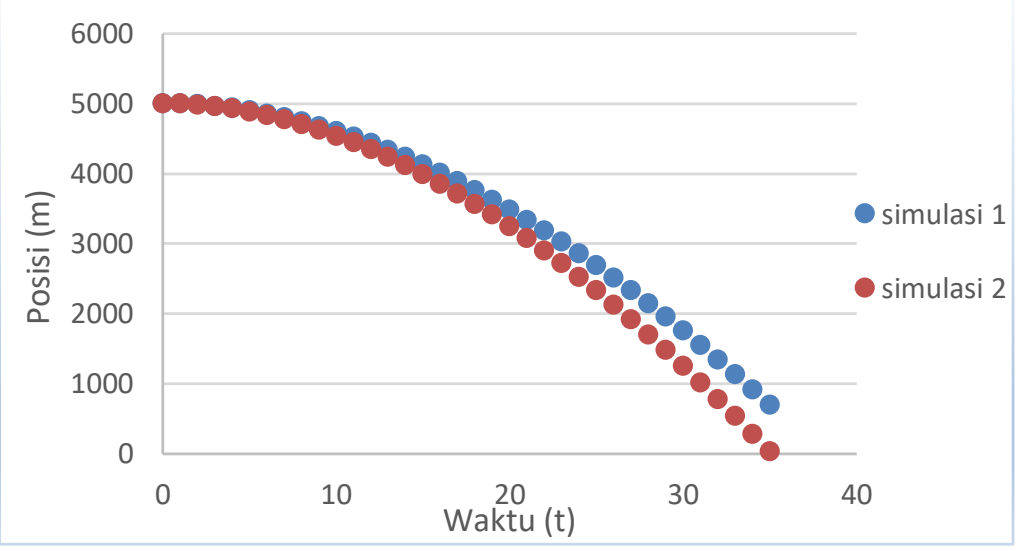

Gambar 5 Pergerakan penerjun payung sebelum parasut dibuka

Pada simulasi pertama dan kedua, penerjun diberikan ketinggian 5000 meter dan hambatan udara $1,44 \mathrm{~kg} / \mathrm{s}$. Pada simulasi pertama penerjun diasumsikan melakukan lompatan dari pesawat dengan posisi track, penerjun mencapai ketinggian 691,43 meter pada detik ke-35. Sedangkan pada simulasi kedua penerjun diasumsikan melakukan lompatan dengan posisi jatuh bebas, penerjun mencapai ketinggian 24,75 meter pada detik ke-51. Pada ketinggian 691,43 meter merupakan waktu yang aman untuk penerjun membuka parasutnya, Jika penerjun membuka parasutnya di bawah ketinggian tersebut maka keselamatan penerjun sangat dikhawatirkan. 


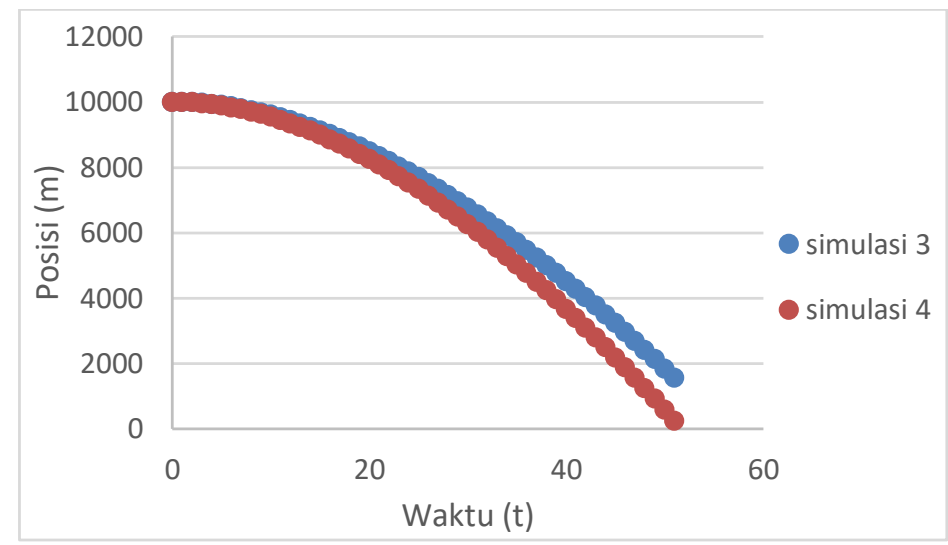

Gambar 6 Pergerakan penerjun payung sebelum parasut dibuka

Pada simulasi ketiga dan keempat, penerjun diberikan ketinggian 10000 meter dan hambatan udara $1,44 \mathrm{~kg} / \mathrm{s}$. Pada simulasi ketiga penerjun melakukan lompatan dari pesawat dengan posisi track, penerjun mencapai ketinggian 1553,20 meter pada detik ke-51. Sedangkan pada simulasi keempat penerjun diasumsikan melakukan lompatan dengan posisi jatuh bebas, penerjun mencapai ketinggian 246,19 meter pada detik ke-51. Pada ketinggian 246,19 meter merupakan waktu yang rawan untuk penerjun membuka parasutnya, Sebaiknya penerjun membuka parasutnya sebelum ketinggian tersebut.

Berdasarkan hasil dari keempat simulasi pergerakan penerjun payung tersebut, dapat dilihat pada saat penerjun melakukan penerjunan dengan posisi track, kecepatan jatuhnya penerjun lebih lama dibandingkan pada saat penerjun melakukan penerjunan dengan posisi jatuh bebas. Pergerakan penerjun pada saat melakukan penerjunan dengan posisi jatuh bebas, jatuhnya lebih cepat dibandingkan pada posisi track. Dari keempat simulasi tersebut dapat dilihat posisi jatuhnya penerjun berpengaruh terhadap kecepatan jatuhnya penerjun selama di udara.

\section{ANALISIS KECEPATAN TERMINAL PENERJUN PAYUNG}

Kecepatan terminal terjun payung merupakan kecepatan dimana besar nilai gaya berat benda $\left(F_{g}\right)$ penerjun sama dengan besar nilai gaya $\operatorname{drag}\left(F_{d}\right)$ atau hambatan udara. Gaya berat yang menyebabkan penerjun bergerak vertikal ke bawah suatu saat akan sama nilainya dengan gaya hambat udara. Karena gaya berat bernilai konstan sedangkan gaya hambat udara semakin meningkat nilainya. Gaya berat memiliki nilai konstan karena hanya dipengaruhi oleh massa dan gravitasi. Sedangkan gaya hambat udara memiliki nilai yang bervariasi sesuai dengan kecepatan penerjun payung. Pada saat penerjun melompat dari pesawat, gaya yang menyebabkan penerjun bergerak adalah gaya berat. Karena penerjun memiliki percepatan gravitasi dari gaya berat maka benda akan bergerak dengan kecepatan yang semakin cepat setiap saat. Namun pada saat penerjun jatuh bebas juga terdapat gaya hambat udara yang dipengaruhi oleh kecepatan penerjun. Jadi disatu sisi gaya berat menambah kecepatan benda namun disisi lain dengan bertambahnya kecepatan juga menambah gaya hambat udara. Gaya hambat udara merupakan gaya penahan yang disebabkan oleh aliran fluida terhadap benda yang bergerak. Dengan bertambahnya gaya hambat udara dan konstannya gaya berat maka suatu saat akan terdapat kesetimbangan, yang artinya besar gaya hambat udara sama dengan besar gaya berat. Sesuai dengan hukum Newton II, maka resultan gaya yang bekerja pada benda akan sama dengan 0. Sesuai dengan hukum Newton I, ketika resultan gaya yang bekerja pada benda sama dengan 0 maka benda cenderung tetap diam atau bergerak dengan kecepatan konstan. 


\section{KESIMPULAN}

Berdasarkan hasil analisis dan pembahasan pada bab sebelumnya, dapat disimpulkan beberapa hal sebagai berikut:

1. Pemodelan matematika pada penerjun payung sebelum parasut dibuka

Model matematika penerjun payung selama di udara:

$$
\begin{gathered}
v(t)=\frac{m g}{k}\left(1-e^{-\frac{k t}{m}}\right) \\
z(t)=z(0)-\frac{m g t}{k}+\frac{m^{2} g}{k^{2}}\left(-e^{-\frac{k t}{m}}+1\right)
\end{gathered}
$$

Model matematika penerjun payung pada posisi track selama di udara:

$$
\begin{gathered}
v(t)=\frac{m g \cos \alpha}{k}\left(1-e^{-\frac{k t}{m}}\right) \\
z(t)=z(0)-\frac{m g t \cos \alpha}{k}+\frac{m^{2} g \cos \alpha}{k^{2}}\left(-e^{-\frac{k}{m} t}+1\right)
\end{gathered}
$$

2. Waktu yang aman digunakan penerjun payung untuk membuka parasutnya jika ia melompat dari pesawat pada posisi track yaitu pada ketinggian 691,43 meter tentunya dengan tetap memperhatikan kondisi sekitar.

3. Besar kecepatan terminal penerjun tergantung berat dan posisi tubuh penerjun selama di udara.

4. Posisi jatuhnya penerjun berpengaruh pada kecepatan pergerakan penerjun payung selama di udara.

\section{DAFTAR PUSTAKA}

[1] Widowati, Sutimin. Buku Ajar Pemodelan Matematia. Semarang: FMIPA UNDIP; 2007.

[2] Asmianto, Hariyanto, Herisman I. Kontruksi Model Matematika Pada Terjun Payung dengan Akrobat Perubahan Posisi Sebelum Parasut Dibuka. Jurnal Sains dan Seni ITS. 2016; Vol. 5.

[3] Ross SL. Differential Equations. Ed ke-3. New York: John Wiley \& Sons Inc; 1984.

[4] Campbell SL, Haberman R. Introduction to Differential Equations with Dynamical System. New Jersey: Princeton University Press; 2008.

[5] Phoenix Fly Tracking Suit [Internet]. 2019 [Cited 2019 Nov 29]. Available from: http://www.chutingstar.com/phoenix-fly-tracking-suit

Desi : Jurusan Matematika FMIPA UNTAN, Pontianak desi12@student.untan.ac.id

Evi Noviani : Jurusan Matematika FMIPA UNTAN, Pontianak evi_noviani@math.untan.ac.id

Yudhi : Jurusan Matematika FMIPA UNTAN, Pontianak yudhi@math.untan.ac.id 